\title{
A PSYCHOLOGY OF
}

\section{DIFFERENCE}





\title{
Otto Rank
}

\section{A PSYCHOLOGY OF DIFFERENCE}

\author{
THE AMERICAN LECTURES
}

Selected, Edited, and Introduced

by Robert Kramer

with a foreword by

Rollo May

PRINCETON UNIVERSITY PRESS

$$
\text { PRINCETON, NEW JERSEY }
$$


COPYRIGHT ㅇ 1996 BY PRINCETON UNIVERSITY PRESS

PUBLISHED BY PRINCETON UNIVERSITY PRESS, 41 WILLIAM STREET,

PRINCETON, NEW JERSEY 08540

IN THE UNITED KINGDOM: PRINCETON UNIVERSITY PRESS, CHICHESTER, WEST SUSSEX

ALL RIGHTS RESERVED

LIBRARY OF CONGRESS CATALOGING-IN-PUBLICATION DATA

RANK, OTTO, 1884-1939.

A PSYCHOLOGY OF DIFFERENCE : THE AMERICAN LECTURES / OTTO RANK ;

SELECTED, EDITED, AND INTRODUCED BY ROBERT KRAMER ; WITH A FOREWORD

BY ROLLO MAY.

P. $\mathrm{CM}$.

INCLUDES BIBLIOGRAPHICAL REFERENCES AND INDEX.

ISBN 0-691-04470-8 (ALK. PAPER)

1. RANK, OTTO, 1884-1939. 2. FREUD, SIGMUND, 1856-1939.

3. PSYCHOANALYSIS-HISTORY. I. KRAMER, ROBERT, 1953-

II. TITLE.

BF109.R345A25 1996

150.19'5-DC20 $95-43758$

THIS BOOK HAS BEEN COMPOSED IN SABON

PRINCETON UNIVERSITY PRESS BOOKS ARE PRINTED

ON ACID-FREE PAPER, AND MEET THE GUIDELINES FOR

PERMANENCE AND DURABILITY OF THE COMMITTEE ON

PRODUCTION GUIDELINES FOR BOOK LONGEVITY

OF THE COUNCIL ON LIBRARY RESOURCES

PRINTED IN THE UNITED STATES OF AMERICA BY

PRINCETON ACADEMIC PRESS

$\begin{array}{lllllllll}3 & 5 & 7 & 9 & 10 & 8 & 6 & 4 & 2\end{array}$ 
In memoriam

Rollo May

(1909-1994) 
